\title{
Development Strategy, Viability, and Economic Institutions
}

\author{
The Case of China
}

\author{
Justin Yifu Lin, ${ }^{1}$ Mingxing Liu, ${ }^{2}$ \\ Shiyuan Pan, ${ }^{3}$ and Pengfei Zhang ${ }^{4}$
}

May 2006

\begin{abstract}
This paper explores the politically determined development objectives and the intrinsic logic of government intervention policies in east developed countries. It is argued that the distorted institutional structure in China and in many least developed countries, after the Second World War, can be largely explained by government adoption of inappropriate development strategies. Motivated by nation building, most least-developed countries, including the socialist countries, adopted a comparative advantage defying strategy to accelerate the growth of capital-intensive, advanced sectors in their countries. In the paper we also statistically measure the evolution of government development strategies and the economic institutions in China from 1950s to 1980s to show the co-existence and coevolution of government adoption of comparative advantage defying strategy and the trinity system.
\end{abstract}

Keywords: development strategy, institution, viability, trinity system JEL classification: O11, P16, P30

Copyright (C) UNU-WIDER 2006

${ }^{1}$ Peking University and Hong Kong University of Science and Technology; ${ }^{2}$ School of Government, Peking University; ${ }^{3}$ Peking University and Zhejiang University; ${ }^{4}$ China Centre for Economic Research, Peking University.

This study is a revised version of the paper presented at the 17-18 June 2005 UNU-WIDER anniversary conference, 'WIDER Thinking Ahead: The Future of Development Economics', directed by George Mavrotas and Anthony Shorrocks.

UNU-WIDER gratefully acknowledges the financial contributions to the research programme by the governments of Denmark (Royal Ministry of Foreign Affairs), Finland (Ministry for Foreign Affairs), Norway (Royal Ministry of Foreign Affairs), Sweden (Swedish International Development Cooperation Agency—Sida) and the United Kingdom (Department for International Development). 


\section{Acknowledgements}

We are grateful to conference and seminar participants at UNU-WIDER, Peking University, and AEA meeting for helpful comments. Two anonymous referees provided very useful suggestions.

The World Institute for Development Economics Research (WIDER) was established by the United Nations University (UNU) as its first research and training centre and started work in Helsinki, Finland in 1985. The Institute undertakes applied research and policy analysis on structural changes affecting the developing and transitional economies, provides a forum for the advocacy of policies leading to robust, equitable and environmentally sustainable growth, and promotes capacity strengthening and training in the field of economic and social policy making. Work is carried out by staff researchers and visiting scholars in Helsinki and through networks of collaborating scholars and institutions around the world.

www.wider.unu.edu publications@wider.unu.edu

UNU World Institute for Development Economics Research (UNU-WIDER)

Katajanokanlaituri 6 B, 00160 Helsinki, Finland

Camera-ready typescript prepared by Lorraine Telfer-Taivainen at UNU-WIDER

The views expressed in this publication are those of the author(s). Publication does not imply endorsement by the Institute or the United Nations University, nor by the programme/project sponsors, of any of the views expressed. 


\section{Introduction}

In recent years, many economists believe that least developed countries (LDCs) failed to catch up with the developed countries because of bad institutions with weak protection for property rights and ineffective constraints on power holders (Acemoglu et al. 2004). At the same time, how to understand government behaviour becomes the most important issue for research on institutions. Both policy reformers and researchers from a very diverse set of perspectives have tried to understand how government intervention and regulation occur and how they can subsequently shape the macro incentive structure that firms in an LDC face.

Although the economists and policymakers have hotly debated the merits of government behaviours and their relationship with the formation of institutions, such issues can be roughly framed within the context of the so-called 'helping hand' (Pigou 1938) versus the 'grabbing hand' taxonomy in the literature. An alternative strand of the grabbing hand view (Shleifer and Vishny 1994) holds that the government interventions are pursued for the benefits of politicians and bureaucrats. For example, politicians use regulations to favour friendly firms and other political constituencies, and thereby obtain benefits such as campaign contributions and votes. 1

Suppose that government regulations in the LDCs could arise from the grabbing hand of government or political elites. The unsolved question in the literature is how to understand the evolution of institutional structure under government interventions. In the LDCs, the institutional structure shaped by government interventions is quite complicated. We wonder what are the incentives for political leaders to design such complicated systems, because the increased expropriation costs and political control due to the complexity of institutions would diminish the gains of grabbing. Corruptions induced by the special interest groups might not be a good answer for this question either, because the benefited groups are often taxed or suppressed alongside with the protections/subsidies. Actually, many interventions do not have obvious beneficiary groups.

Beyond the views from the helping and grabbing hand categories, there are also other theories suggesting that government regulations and controls over firms in the developing countries might root in the high cost of collecting public funds and the poor taxation system. For example, Gordon and Li (2005a, b) argued that the financial disintermediation and informal economy might make tax enforcement difficult, and politicians have to design the distorted structure of taxation and red tape towards industry. Or, as the administrative weakness is exaggerated, government is likely to control the production capacity directly by state ownership (Esfahani 2000). Such existing viewpoints definitely

1 A recent paper by Djankov et al. (2002) provided an empirical test on theories of the grabbing hand, say, the barrier for business entry might arise from corrupt bureaucrats. 
reveal some intrinsic features of government behaviours in LDCs, but the characteristics of institutional structure are still partially captured. Actually, the regulatory policies adopted in LDCs are much more complicated than their theoretical settings. In addition, the researchers also offer few insights into the motivations of politicians to collect the public funds overburdening the economy.

This paper will explore the politically determined development objectives and the intrinsic logic of government intervention policies with the comprehensive implications for institutional building in LDCs. We argue that the distorted institutional structure in China and many LDCs after the Second World War can be largely explained by government adoption of inappropriate development strategies. Motivated by nation building, most LDCs, including the socialist countries, adopted a CAD (comparative advantage defying) strategy to accelerate the growth of capital-intensive, advanced sectors in their countries. Many firms in the priority sectors of CAD strategy were non-viable in open, competitive markets because they did not have comparative advantage in the priority sectors. Therefore, to maximize resource mobilization for building up the priority sectors and to support nonviable firms in those sectors, a regulatory system had to be established. According to Lin et al. (1996, 1999, 2003), such a system was characterized by the trinity of a macro-policy environment of distorted prices for products and essential factors of production (for example, trained personnel, funds, technologies, resources, etc.), highly centralized planned resource allocation and a micro-management mechanism in which firms had no decision making powers.

First, if government wants to implement a CAD strategy and promote the status of capitalintensive industry, it must either distort artificially the relative prices of factors and products, or subsidize the heavy industry sector by collecting taxes from the light industry sector. Owing to information asymmetry, costs for the heavy explicit tax collection are prohibitively high. The government then has to resort to artificially distorting relative prices of input factors and products, for example, depressed interest rate, exchange rates and prices of popular goods, prerequisite for the prioritized development of the heavy industries. Second, when the price of a product or a factor is artificially set below its equilibrium price, the demand will be stimulated and the supply will be suppressed. Implementing the planned resource allocation system was the objective demand to solve the contradiction that gross demand exceeds gross supply under the distorted macro policy environment and to guarantee resources go to prioritizing industries. Third, the planning system makes the imbalance of returns between the light and heavy industries, which drives the firms transfer of resources to non-prioritized industries. Alternatively, with the missing competition and the distorted prices, the profitability of an enterprise is not determined by its performance. If the firm were given autonomy, due to the information asymmetries between the government (the principal) and the firm manager (the agent), managers and workers would inevitably prey upon its profit and assets. To avoid the investment arbitrage and the erosion of profits and state assets, the state has to deprive enterprises of autonomy. 
We will statistically measure the evolution of the development strategy of government and the economic institutions in China from 1950s to 1980s, including the deviation of industry structure from the fundamentals, the distorted relative prices both for the agricultural and industrial products and endowment factors, scope of material allocation by state, and the extent of state ownership of industrial firms. It shows that this trinity system of government controls does exist concurrently with CAD strategy.

\section{CAD strategy and viability}

After the Opium War of 1840, China, once an influential nation, began to decline. Chinese political leaders and intellectuals devoted their lives to the ideals of a strong nation and a prosperous people. In 1949, the founding of the People's Republic marked a new era of China's history. According to China's development level and the knowledge available to its leaders at that time, industrialization was virtually synonymous with economic development and the goal of eliminating poverty and backwardness. The ambitious government leaders believed that to defend the newly established socialist system, and to keep pace and even overtake Western industrial countries, rapid industrial development, especially the establishment of heavy industry, were essential.2

Learning mainly from the Soviet experiences, the Chinese government began to formulate and implement the first Five-Year Plan that gave priority to heavy industrial development from 1953. In the first Five-Year Plan, heavy industrial development was put in a strategic position. The central and backbone projects of industrial construction in the first Five-Year Plan were the 156 key projects designed with aid from the former Soviet Union. During the first five year period, investment in heavy industrial infrastructure accounted for 85 per cent of total industrial infrastructure and 72.9 per cent of total investment in agricultural and industrial infrastructure.

However, the development strategy of prioritizing heavy industries was inconsistent with China's endowment structure. During the initial period of China's economic development, capital was in very short supply, hence market interest rates were naturally high while labour was rather cheap. The cost of developing capital-intensive heavy industries was extremely high and such industries would have no competitiveness in an open and free competitive market economy. 3 If resources had been allocated by the market mechanism, investment would not have flowed to heavy industry sectors. Rather, industrialization with light industry would have occurred, which would have been contradictory to the goal of implementing the heavy industry-oriented development strategy. To support the non-viable

\footnotetext{
2 The development strategy is exogenously determined by political consideration. In fact, in addition to China and socialist countries, many non-socialist developing nations, notably those in South Asia and Latin America, made similar choices, and their economic systems had many features in common with the Chinese system. For the discussion on the historical causes of CAD strategy, see Lin et al. (2003: chapter 2).
}

3 See Lin and Tan (1999). 
firms, institutional arrangements were made, and the barriers to heavy industry development were lowered artificially. Then, the catch-up strategy, the distorted macropolicy environment, the planned resource allocation system and the rigid micromanagement institutions would be left intact.

To illustrate how the viability problem may arise, assuming there is a simple economy that possesses two given factor endowments, capital and labour, and produces only one good. Each point on the isoquant shown in Figure 1 represents a technology of production or a combination of capital and labour required to produce a given amount of a certain product. The technology represented by $A$ is more labour intensive than that of $B . C_{1}, C_{2}$, and $C_{3}$ are the isocost lines. The slope of an isocost line represents the relative prices of capital and labour. In an economy where capital is relatively expensive and labour is relatively inexpensive, as represented by isocost lines $\mathrm{C}_{2}$, and $\mathrm{C}_{3}$, the adoption of technology $\mathrm{A}$ to produce the given amount of output will cost the least. When the relative price of labour increases, as represented by the isocost lines by $C_{1}$, production will cost the least if technology B is adopted.

Figure 1: Viability and economic institution

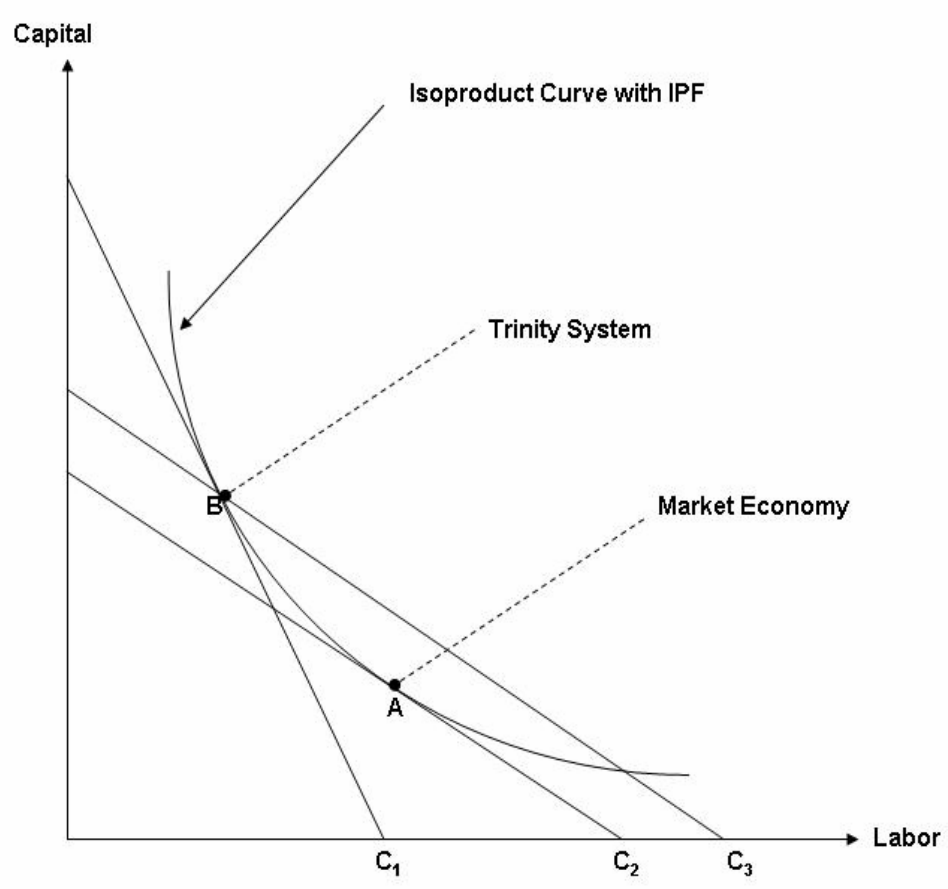

In a free, open, and competitive market economy, a firm will be viable only if it adopts the least-cost technology in its production. In Figure 1, if the relative prices of capital and labour can be presented by $\mathrm{C}_{2}$, the adoption of technology A costs the least. Market competition will make firms that adopt technologies other than A nonviable. On the other 
hand, the relative prices of capital and labour are determined by the relative abundance/scarcity of capital and labour in the economy's factor endowments. Therefore, the viability of a firm depends on whether its choice of technology is on the least-cost lines determined by the factor endowments of the economy. Most importantly, we need to clearly define the indicators measuring development strategy. According to Lin (2003), we construct a technological choice index (TCI) based on the capital intensity of the manufacturing sector to measure a country's choice of development strategy and in turn the quality of policy and institutional environment of that country

$$
T C I_{i t}^{1}=\frac{\left(M K_{i t} / M L_{i t}\right)}{K_{i t} / L_{i t}}
$$

where $M K_{i t} / M L_{i t}$ is the capital-labour ratio of the manufacturing sector, and $K_{i t} / L_{i t}$ is the capital-labour ratio of the $i$ th economy in year $t$. This index not only reflects how much the government's preference for developing capital-intensive industries is, but also can be used to measure how much the economy is distorted by the government. Given the development stage of a country, the higher this index is, the more an economy is distorted. Lin (2003) found this index well explained the economic growth in a cross-country empirical analysis. An alternative measurement for development strategy is defined as

$$
T C I_{i t}^{2}=\frac{A V M_{i t} / G D P_{i t}}{L M_{i t} / L_{i t}}
$$

where $A V M_{i t}$ is the added value of manufacturing industries of the $i$ th country in year $t$; $G D P_{i t}$ is the GDP of the ith country in year $t ; L M_{i t}$ is the labour in the manufacturing industry, and $L_{i t}$ is the total labour of ith country in year $t .4$ If a government adopts a CAD strategy to promote its capital-intensive industries, this index is expected to be larger than otherwise. This is because a country that adopts a CAD strategy in its manufacturing industries will be more capital intensive and absorb less labour ceteris paribus. So, two measures have the similar nature in statistics. Figure 2 shows the basic description about the TCI 1 and 2 for China from 1952 to 2002.5

\footnotetext{
4 The industry data on the output, the fixed capital stock and labour was collected from various issues of China Industry Statistical Yearbook, and the total value of fixed capital stock was devaluated by the index of fixed-asset investment price taken from the various issues of China Statistical Yearbook. The national data on the output, the fixed capital formation, and labour was collected from China Compendium of Statistics 19492004 and various issues of the China Statistical Yearbook. The capital stock at national level was calculated by the perpetual-stock method.
}

5 Two indicators measuring CAD strategy miss capturing the policy change and distortion during the Great Leap Movement. The government produced the poor-quality iron and steel by the backyard furnaces and millions of farmers were forced to join into the iron and steel manufacturing instead of harvesting the crops. The number of industry workers increased from 14.02 million in 1957 to 44.16 million in 1958 and decreased to 28.79 million in 1959. That is, although the government launched a political movement for a faster pace 
Figure 2: TCl1 and TCl2 in China (1952-2002)

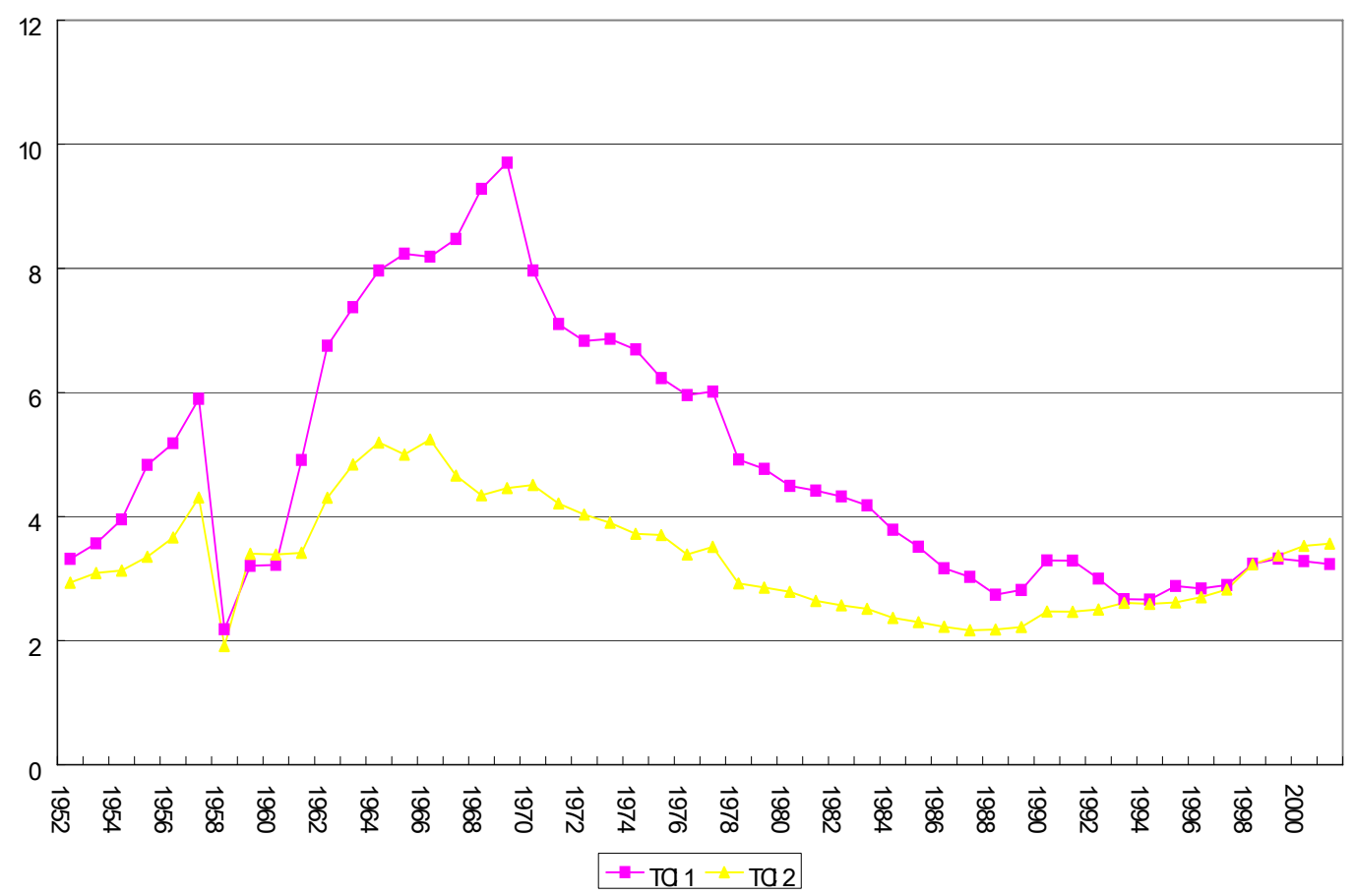

\section{The trinity system in China}

To maximize the resource mobilization for the capital-intensive-oriented industrialization, a planned system had to be established. The logic for the trinity of intervention policies characterizing the CAD strategy is as follows:

(1) A macro policy environment with depressed interest rate, exchange rate and prices of popular goods was prerequisite for prioritized development of heavy industry.

(2) Implementing the planned resource allocation system was the objective demand to solve the contradiction that gross demand exceeded gross supply under the distorted macro policy environment and to guarantee resources went to heavy industries.

(3) The micro management institution without any autonomy was implemented in order to prevent enterprises from corroding profits and state assets taking advantage their operation rights. In the rural areas, the People's Commune system was to guarantee state monopoly of procurement and marketing of agricultural produces.

Due to this huge scale, the government had to collect heavy explicit taxes from the economic sectors that were generating a surplus and create direct financial subsidies for the non-viable industries. But such a surplus would have come only from the small and

industrialization, but the technology level for industrial production was low. However, capital-labour ratio measures the embodied technology level in the production, while TCI means the deviation of technology adoption in the industry from the fundamentals. Then, by these measures, the CAD strategy reached the peak in accord with the 'Three Line Construction' in the late 1960s, other than the 'Great Leap Movement'. 
scattered agricultural sector, making tax collection difficult and costly. The key to supporting the non-viable firms was to completely reject market mechanisms by artificially distorting the relative prices of factors and products. The cost of developing heavy industries had to be decreased artificially, while resource mobilization-including the supply of cheap labour, funds, raw materials, imported equipment, and technology - had to be improved. As a result, a macro policy environment was needed to allocate resources in a way that would encourage the development of heavy industries. Such a policy environment includes various components:

(1) The most important condition needed for fast, low-cost growth of heavy industry is low-price capital, so a low interest rate policy and other financial repression policies were adopted by the government.

(2) To ensure that key projects could import the critical equipments at low prices, the Chinese government had to interfere in the formulation of the foreign exchange rate by artificially overvaluing home currency and by instituting a low exchange rate policy.

(3) Following the policies for reducing capital costs, the government suppressed the cost of labour and other inputs (so-called 'a policy of low nominal wages and low prices for energy and raw materials') in order to enhance the potential for surplus accumulation of heavy industry.

(4) The low-wage policy held down the purchasing power of urban residents. The solution for sustaining worker welfare was to set low prices for agricultural products and essential goods and services. Because large-scale industries were concentrated in urban areas, the low-cost policy was targeted toward urban populations, and rural populations did not benefit from it.

Figure 3: Price premium of agricultural products in China (1952-83)

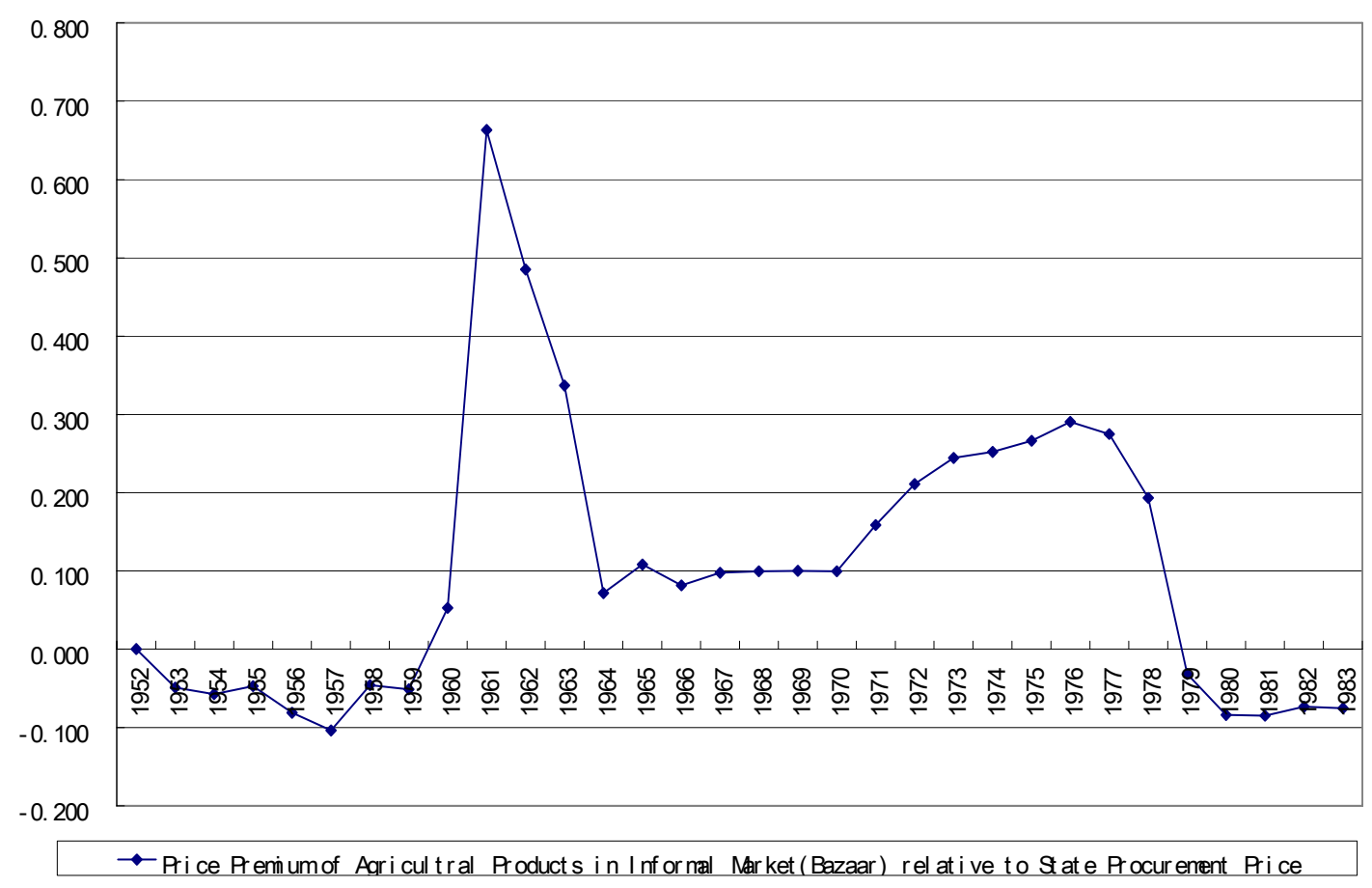


Due to the policy of low prices for agricultural products and other essential goods and services, a large proportion of the costs of heavy industry development were transferred to traditional economic sectors such as agriculture. In Figure 3 we compare the price level of grain in the rural informal market with government procurement prices to indicate how the relative price of the agriculture was suppressed under the traditional macro policy environment from 1950s to 1980s.

A macro policy environment that distorts prices of products and production factors thus causes a serious imbalance between the supply and the demand of funds, foreign exchange, raw materials, agricultural products, and other basic necessities. If the market had been allowed to direct resource allocation, the policy of suppressing prices could not have ensured that these resources would flow to strategic sectors. To replace the role of the market in allocating resources and also to ensure that materials and resources in short supply would be allocated to prioritized industries, the government had to create a new set of institutions.

Figure 4: Share of budgetary appropriation in investment on capital construction in China (1952-2002)

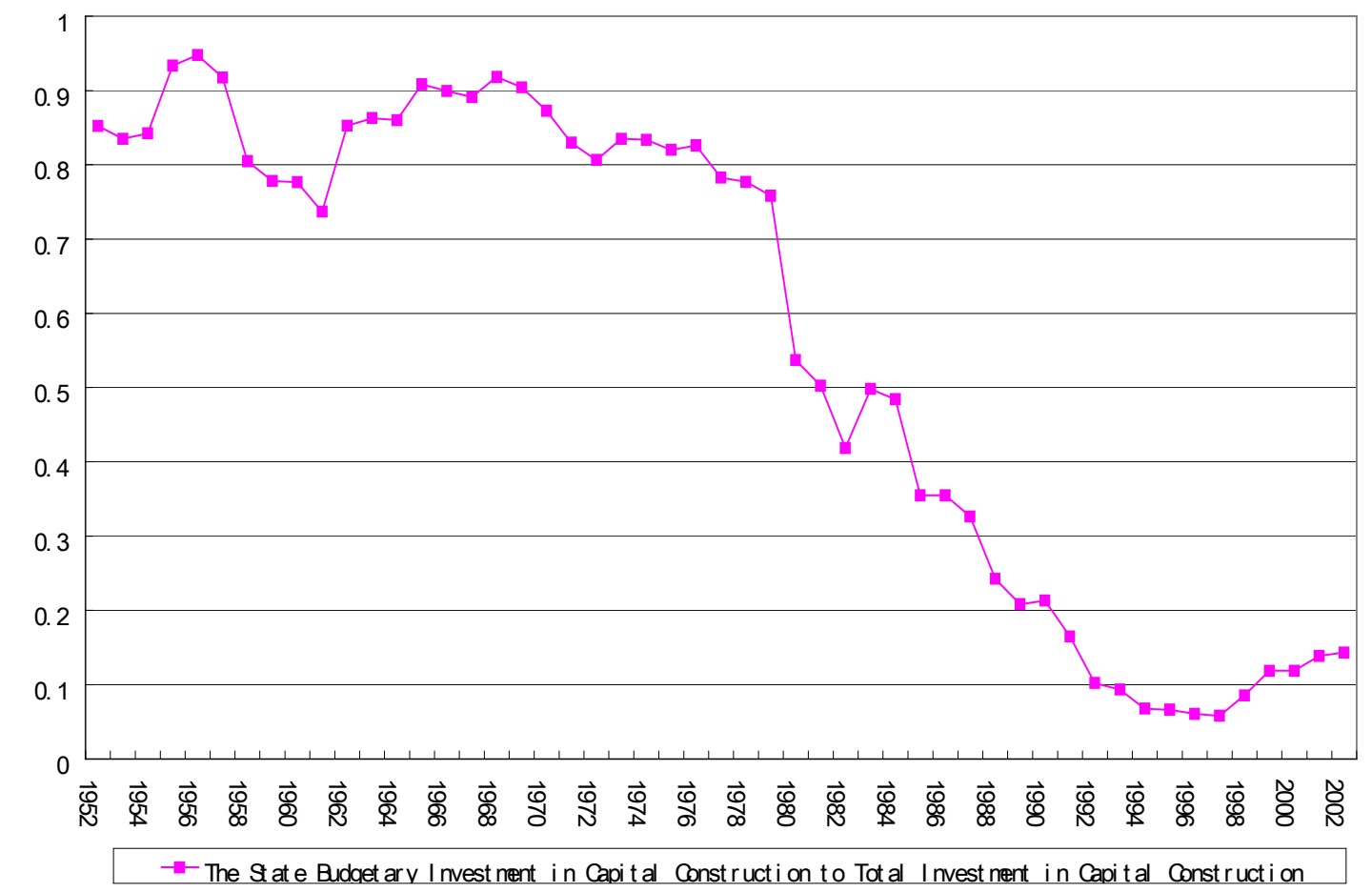

The planned administrative means can be summarized as follows. (1) The first step was to establish a financial administration institution. Between 1949 and 1952, China gradually completed the primary nationalization of banks. In 1953, the People's Bank of China established credit plan managerial bureaus at various levels of its underling banks to work out and implement overall credit and loan plans. Within the bank, a corresponding credit fund internal control system with unified revenue and expenditure management was imposed. (2) The second step was to establish a management system for foreign trade and exchange. The state made a unified arrangement for imports and exports by imposing a monopoly over foreign trade and a highly controlled regulatory system over foreign trade 
and exchange. (3) The third step was to establish a monopoly system to manage the allocation of materials and the procurement and marketing of agricultural products. Based on these administrative means, most of resource allocation was controlled by government. From Figure 4, we can find a large proportion of capital construction investment in China was allocated by the fiscal budget directly before economic reform.

To manage the planning system, China established the State Planning Commission in 1953, whose function was to allocate important materials across the country. The commission classified the materials into three categories: (1) materials under the unified allocation of the state; (2) materials under allocation by state industrial ministries and commissions under the state council; and (3) materials under the allocation of the local administration. Table 1 shows the basic figures for the materials of the first two categories from 1950s to 1980s. From 1953-57 the number of different types of industrial products under direct distribution by the government increased rapidly. The types of materials under unified distribution increased from 227 to 532. But, after the economic reform, the direct allocation by the state of materials dramatically decreased in 1980s.

Table 1: Number of types of materials under government control in China (1950-88)

\begin{tabular}{|c|c|c|}
\hline Year & $\begin{array}{l}\text { Under the unified state } \\
\text { distribution system }\end{array}$ & $\begin{array}{l}\text { Under the mandatory plans of corresponding } \\
\text { departments in state council }\end{array}$ \\
\hline 1950 & 8 & \\
\hline 1951 & 33 & \\
\hline 1952 & 55 & \\
\hline 1953 & 112 & 115 \\
\hline 1954 & 121 & 140 \\
\hline 1955 & 162 & 139 \\
\hline 1956 & 234 & 151 \\
\hline 1957 & 231 & 301 \\
\hline 1958 & 93 & 336 \\
\hline 1959 & 67 & 218 \\
\hline 1960 & 75 & 342 \\
\hline 1961 & 87 & 416 \\
\hline 1962 & 153 & 345 \\
\hline 1963 & 256 & 260 \\
\hline 1964 & 370 & 222 \\
\hline 1965 & 370 & 222 \\
\hline 1966 & 326 & 253 \\
\hline 1972 & 49 & 168 \\
\hline 1973 & 50 & 567 \\
\hline 1975 & 52 & 565 \\
\hline 1978 & 53 & 636 \\
\hline 1979 & 210 & 581 \\
\hline 1981 & 256 & 581 \\
\hline 1988 & 27 & 45 \\
\hline
\end{tabular}

Source: Authors. 
There was a strong demand for light industry goods because of insufficient market supply; at the same time, the technological structure of light industries catered well to the comparative advantages of the Chinese economy. With the state focused on developing heavy industry, investment in the suppressed industries would tend to yield high returns. Because the profit-oriented private enterprises would allocate their resources to the sectors that yielded the highest returns, the state had to nationalize private enterprises. Figure 5 shows that government made a big push for the nationalization movement towards the industrial firms in 1950s.

Figure 5: Share of SOEs in industrial output in China (1952-98)

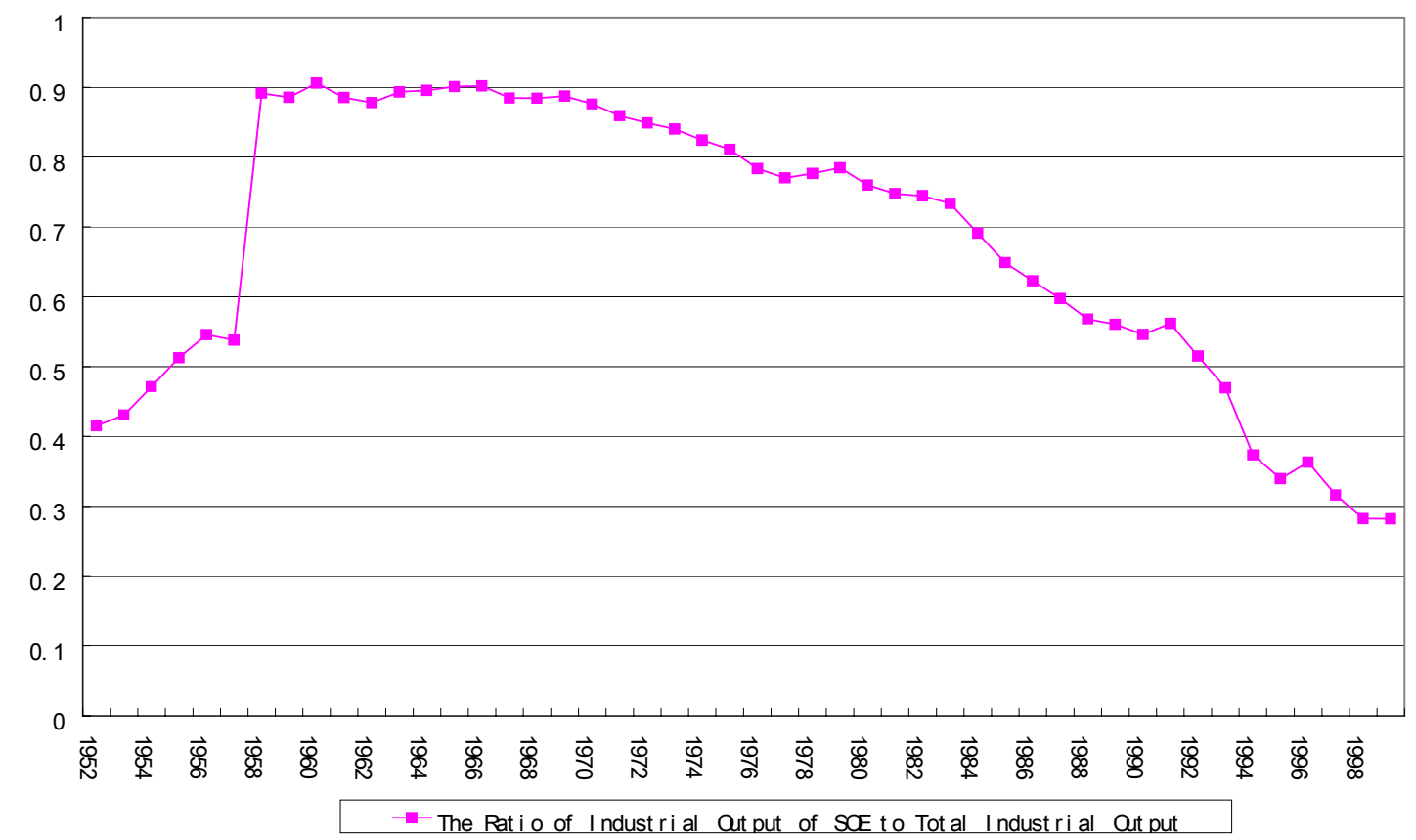

Because of information asymmetry, monitoring costs to state-owned enterprises (SOEs) for the state was prohibitively high. In particular, since prices were distorted by macro policy, profits and losses ceased to reflect management's performance. When competition was eliminated after private enterprises were artificially destroyed, and the allocation of goods and resources was carried out only by the state, profits and losses for enterprises in an industry ceased to be a function of their market competitiveness. Under these conditions, it was impossible for SOEs with autonomy in production and management to avoid encroaching on the surplus. As a result, on the basis of an ownership arrangement, the state chose to deprive SOEs of any autonomy. All production materials used by SOEs were supplied by the government, and all their output was sold to and allocated by the state. And, it was imperative to establish a compulsory production plan system and a unified revenue and expenditure system.

Accompanying the nationalization of industry, the collectivization of agriculture through the People's Commune System was also accelerated, which was an important step toward realizing the state monopoly policy of procurement of agricultural products at a low price. If the state wishes to increase the quantity of agricultural product procurement, it must 
exercise direct control over agricultural production. Collectivization should be an institutional arrangement by which the government can upgrade its direct control over agricultural production. 6

Here, we trace the formation of the trinity system in accord with the enforcement of CAD strategy in China. Obviously, a highly centralized trinity system inevitably undermined the incentives of local agents. To facilitate the implementation of central targets, some measures were adopted for local government and SOEs in the pre-1978 reforms, which included (1) eliminating the central government's over-concentration of power by decentralizing administrative authority and responsibility; and (2) eliminating unequal distribution of benefits among regions and sectors by adjusting their administrative authority and responsibility. As a special case, in early 1960s, the central government decentralized the autonomy to the farmers in order to recover the agricultural production from the Great Famine. However, the decentralization under a trinity system was not able to solve the inefficiency problem since it could neither improve micro efficiency through market discipline, nor change the heavy industry development strategy inconsistent with China's comparative advantage. These reforms had not touched on the basic framework of the trinity system. Under the soft budget constraints faced by local government and SOEs, a cycle of decentralization leading to disorder, disorder leading to centralization, centralization leading to stagnation, and stagnation leading to decentralization was inevitable. In terms of this centralization cycle, the trinity system supporting the CAD strategy was not a stable institution.

The economic reform that began in 1978 signified Chinese leaders' search for a new path of economic development. The basic framework of trinity system and CAD strategy was no longer off limits, this enabled reform to penetrate all levels of the economic system. During this thorough and increasingly powerful reform compulsory plans were gradually replaced by indicative plans, and the planned allocation mechanism was replaced by a market mechanism. The new economic system gradually took shape. Our empirical measures could roughly capture the formation and collapse of trinity system. Comparing Figures 2-5 and Table 1, a co-movement trend can be found for the indicators measuring the economic institution and development strategy in China's history. The measures peaked in the 1960s, and decreased gradually in 1970s, which means the changing structure of economic institution can be explained by the choice of development strategy.

6 An example is the Great Leap Forward Movement in economic construction launched in 1958, which proposed that China might surpass the United Kingdom's level of economic development and catch up to that of the United States in ten years. Heavy industries were emphasized, especially iron and steel. Several preposterously high indicators of industrial development were fabricated. At the same time, the nationalization movement and policies for planning control were also pushed. Because of the inappropriate ratio of accumulation and the shortage of consumption funds, and also because agricultural production could not meet increasing needs, the government had to increase compulsory procurement quotas. In 1958, grain production increased by 2.55 per cent, but the quantity procured rose by 22.3 per cent. At the same time, agricultural collectivization was suddenly accelerated to ensure the low-price procurement of agricultural products. As is well known, its consequences were disastrous. 


\section{Conclusion}

According to Lin's various studies, many developing countries, including those socialist countries such as Russia, East Europe Countries and China, and even many Latin American countries and India, that adopted an import substitution strategy after the Second World War were actually adopting a forward moving development strategy. However, for most LDCs, capital was in short supply; hence the market interest rate was naturally high, while the cost of labour was low. Developing capital-intensive heavy industries was thus extremely costly, and such industries could not hope to be viable in an open, free market economy. Thus, the government had to distort the economic institution, and nationalize the resources, so as to sustain the non-viable industry. From this perspective, our study sheds light on the inherent laws for a variety of regulatory policies and intervention syndromes in LDCs in an integrated framework, which can be summarized as a trinity system including the macro policy environment, highly centralized planned resource allocation system and dependent micro management institution. This point is in contrast with the existing theories of political economy, the so-called helping hand versus grabbing hand taxonomy. That means, heavily regulations on the economy in LDCs might not be due to the corruption of politicians or manipulation of interest group, but the CAD strategy by government.

Although we illustrate the above argument only by the empirical evidence of China, the formation of the trinity system as a result of the adoption of a CAD strategy should not be unique to China or particular to the socialist system. Therefore, the formation, consequences, and reform process of China's traditional economic institution have valuable implications for other socialist economies and developing countries that adopted the development strategies similar to China's. In short, the liberalization reforms will depend on the final removal of the viability problem that exists in many firms in the priority sectors under the previously adopted CAD strategy.

\section{References}

Acemoglu, D., S. Johnson, and J. Robinson. (2004). 'Institutions as the Fundamental Cause of Long-Run Growth', in P. Aghion and S. Durlauf (eds) Handbook of Economic Growth, North Holland: Amsterdam.

Djankov, S., R. La Porta, F. Lopez-de-Silanes, and A. Shleifer (2002), 'Regulation of Entry,' Quarterly Journal of Economics 117(1): 1-37.

Esfahani, H.S. (2000). 'Institutions and Government Controls', Journal of Development Economics 63: 197-229.

Gordon, R., and W. Li (2005a). 'Tax Structure in Developing Countries: Many Puzzles and a Possible Explanation,' NBER Working Papers 11267, National Bureau of Economic Research: Cambridge MA. 
Gordon, R., and W. Li (2005b). 'Financial, Taxation, and Regulatory Structures in Developing Countries', mimeo.

Lin, J.Y., 'Development Strategy, Viability and Economic Convergence', Economic Development and Cultural Change 53(2): 277-308.

Lin, J.Y., F. Cai, and Z. Li (1996). China’s Miracle: Development Strategy and Economic Reform, Chinese University of Hong Kong Press: Hong Kong.

Lin, J.Y., and G. Tan. (1999). 'Policy Burdens, Accountability, and the Soft Budget Constraint', American Economic Review : Papers and Proceedings 89(2): 426-31.

Pigou, A. (1938). The Economics of Welfare, Macmillan: London.

Shleifer, A., and R.W. Vishny (1994). 'Politicians and Firms', Quarterly Journal of Economics 109: 995-1025. 